OPEN ACCESS

Edited by:

Urs Feller,

University of Bern, Switzerland

Reviewed by:

Emma Louise Burns,

Australian National University, Australia Harminder Pal Singh,

Panjab University, India

*Correspondence:

Helen Treichel

helentreichel@gmail.com

Specialty section:

This article was submitted to Agroecology and Ecosystem Services, a section of the journal Frontiers in Sustainable Food Systems

Received: 17 December 2019

Accepted: 24 September 2020

Published: 23 October 2020

Citation:

Stefanski FS, Camargo AF, Scapini T,

Bonatto $C$, Venturin $B$, Weirich $S N$, Ulkovski C, Carezia C, Ulrich A,

Michelon W, Soares HM

Mathiensen A, Fongaro G, Mossi AJ and Treichel $H$ (2020) Potential Use of Biological Herbicides in a Circular Economy Context: A Sustainable doi: 10.3389/fsufs.2020.521102

\section{Potential Use of Biological Herbicides in a Circular Economy Context: A Sustainable Approach}

\author{
Fábio Spitza Stefanski ${ }^{1}$, Aline Frumi Camargo ${ }^{1}$, Thamarys Scapini ${ }^{1}$, Charline Bonatto ${ }^{1,2}$, \\ Bruno Venturin ${ }^{1}$, Sabrina Natalia Weirich ${ }^{3}$, Cleiton Ulkovski ${ }^{3}$, Carine Carezia ${ }^{3}$, \\ Alessandro Ulrich ${ }^{3}$, William Michelon ${ }^{4}$, Hugo Moreira Soares ${ }^{4}$, Alexandre Mathiensen ${ }^{5}$, \\ Gislaine Fongaro ${ }^{6}$, Altemir José Mossi $^{3}$ and Helen Treichel ${ }^{1 *}$ \begin{abstract}
and Food Engineering, Federal University of Santa Catarina, Florianópolis, Brazil, ${ }^{3}$ Laboratory of Agroecology, Federal University of Fronteira Sul, Erechim, Brazil, ${ }^{4}$ Departament of Chemical Engineering, Federal University of Santa Catarina, Florianópolis, Brazil, ${ }^{5}$ Embrapa Swine and Poultry, Concórdia, Brazil, ${ }^{6}$ Laboratory of Applied Virology, Department of Microbiology, Immunology and Parasitology, Federal University of Santa Catarina, Florianópolis, Brazil
\end{abstract} \\ ${ }^{1}$ Laboratory of Microbiology and Bioprocess, Federal University of Fronteira Sul, Erechim, Brazil, ${ }^{2}$ Department of Chemical
}

In recent years, synthetic herbicides' intense and disordered use has triggered severe contamination of soils and water bodies, causing damage to living organisms, including vegetal herbicide-resistance. In-part, biological herbicides, offer promise in addressing these problems, especially for sustainable weed management in both agricultural and natural resource management contexts. The search for culture media to serve as alternatives to the existing conventional synthetic media has focused on microalgae biomass. The natural properties of these organisms make them ideal raw materials for fermentative processes. Therefore, this study aimed to integrate bioprocesses producing bioherbicidal extract using a submerged fermentation process. For this, a substrate of microalgae recycled biomass to replace commercially used media for fungal growth for relatively cheap biomass obtained from wastewater phycoremediation after anaerobic treatment (UASB). We also verified its potential for weed control. Preliminary tests of microalgae fermentation were conducted in the raw and lyophilized form, using the fungus Trichoderma koningiopsis. To evaluate their phytotoxic potential, the biocompounds were applied to Bidens pilosa, Conyza bonariensis, Urochloa plantaginea, and Euphorbia heterophylla weeds. A central composite rotatable design (CCRD) was used to evaluate the influence of temperature $\left(20-45^{\circ} \mathrm{C}\right)$, agitation (0-200 $\mathrm{RPM})$, and $\mathrm{pH}(3-14)$ on the improvement of enzyme activities, fungal growth and the effects on Cucumis sativus germination tests. We found that microalgae could be used as a substrate for obtaining bioherbicides. The biocompounds produced in this study were relevant for pre- and post-emergence control of model plants (Cucumis sativus), with vigor indexes of up to $8.05 \%$ and herbicide-resistant plants (Conyza bonariensis) with phytotoxic damage of up to $100 \%$ after 15 days. From the experiments' design, we found that agitation was the variable that had the most significant effect on enzyme and biomass production, followed by $\mathrm{pH}$ and temperature. The enzymes also showed synergistic action when acting together with microalgae and fungi, potentiating the control effect 
on weeds. Finally, the system integrated bioprocesses through agro-industrial effluent recovery and reuse, considered one of the essential economic viability mechanisms by enhancing the development of more sustainable technologies that embrace the principles of a circular economy.

Keywords: bioherbicide, sustainable weed management, residual biomass valuation, circular economy, design of experiments

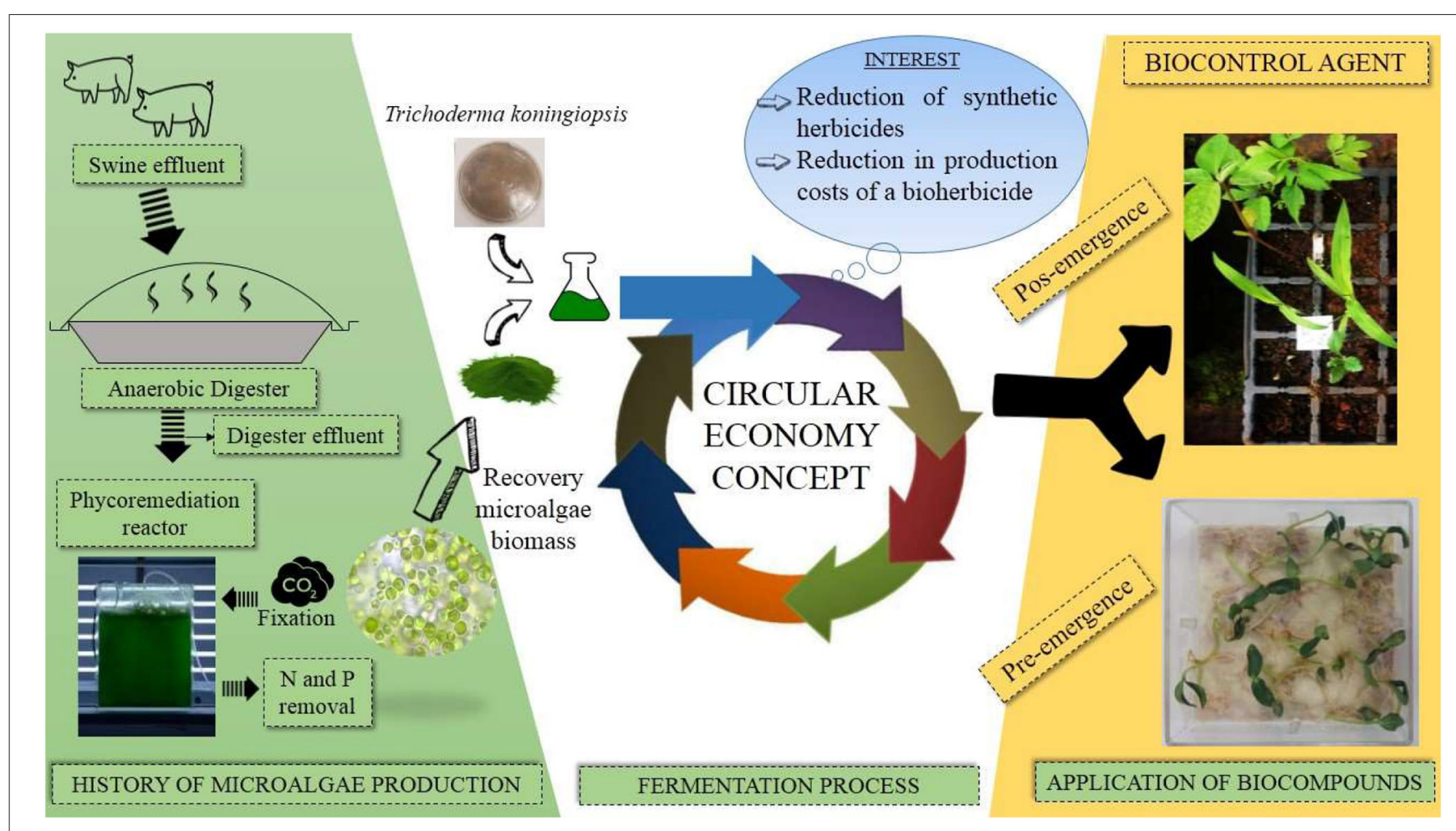

GRAPHICAL ABSTRACT |

\section{HIGHLIGHTS}

- Bioherbicides as alternatives for weed management;

- Valuation of microalgae biomass substitutes for synthetic fermentative medium;

- Bioherbicides produced by fungus and microalgae selectively control Conyza bonariensis;

- Enzymes and bioherbicides have synergistic action in weed control.

\section{INTRODUCTION}

One of the narrowest bottlenecks of modern agriculture, preventing productivity, is the presence of hardy weeds. Natural ecosystem dynamics may drive this phenomenon; however, herbicides used to control these plants bear substantial responsibility for generating resistance (Perotti et al., 2020). They can be found in all parts of landscape and property, including rural, urban, coastal, national parks, and private farms, forming large dense patches threatening the ecosystem (Department of Environment Conservation, 2006).

The presence of weeds in agricultural fields can generate annual crop losses of more than the U.S. $\$ 100$ billion worldwide (Appleby et al., 2000). The global consumption of herbicides for managing these weeds is about 95 million tons per year, representing the share of $47.5 \%$ among all pesticides used in the world (De et al., 2014). The strong dependence on the intensive and disordered synthetic herbicides for weed control has been questioned for many years. The problems resulting from their overuse have been increasingly frequent and significant. As a result, the public's concern with synthetic herbicides' environmental safety has increased interest in developing alternative methods that are efficient in controlling weeds and minimizing ecological impacts (Cordeau et al., 2016).

A more sustainable alternative for weed management is bioherbicides produced through secondary fungal and plant metabolites. These bioproducts are emerging in the weed control 
area because they provide a more sustainable pathway for modern agriculture (Cordeau et al., 2016; Todero et al., 2018). The use of microorganisms in agriculture can promote or reduce invasive plants' development as a form of biocontrol and to protect the environment (Boyette and Hoagland, 2015; Radhakrishnan et al., 2018). The restructuring of biodiversity in terms of richness, diversity, and uniformity after applying bioherbicides was more significant than synthetic herbicides (Zhang et al., 2019).

In many countries, bioherbicides are an emerging technology for biological control. There are few bioherbicides on the market, and most are aimed at the organic market and have few or no technical details on application costs. Thus, it is a great challenge to obtain this information since this content is not available in the public domain, either through published patents or scientific publications (Mupondwa et al., 2015). So far, more than 20 bioherbicides have been officially registered worldwide (Zhang et al., 2019). Some of which have already had their sales interrupted due to production and marketing costs. Others are still in the testing phase to overcome commercialization challenges and competition with cheaper synthetic herbicides (Cordeau et al., 2016).

To date, few studies provide a complete techno-economic evaluation in studies involving the production of bioherbicides by the microbial route. More than $50 \%$ of the operating costs for formulating a bioherbicide are associated with raw material acquisition when commercial and chemically defined (Mupondwa et al., 2015). Microalgae biomass in fermentation processes is a relatively recent issue. Some microalgae can be grown in residues from the production of biogas, the digested ones, to recycle nutrients such as phosphorus and nitrogen present in this material. In biotechnological processes, residual biomass presents potential as fermentative substrates. It is a cheap source of raw material and rich in proteins and carbohydrates. Thus, the reintegration of this biomass in new processes allows the development of the circular economy, adding value to its use, bringing economic viability through the use of cheap and environmental biomass for the proper management of residues from biogas production (Michelon et al., 2016; Stiles et al., 2018; Drumm et al., 2019).

Recycled microalgae biomass allows simultaneous organic waste management and supplementation through its use as a substrate to improve fermentation performance and end-product efficiency. The application of these microalgae from digestate management provides a circular economy developmental approach, enabling alternative uses of the same biomass and establishing promising solutions in food and environment security (Stiles et al., 2018). Recycled microalgae biomass is promising in biotechnological processes, as are bioherbicides because they are strategies that aim to minimize the exploitation of natural resources and costs. They seek the insertion of more natural and eco-friendly products into the global market. Therefore, the study aimed to integrate bioprocesses producing bioherbicidal extract with a submerged fermentation process using recycled microalgae biomass as a substrate. The aim was to replace commercially-available media for fungal growth for relatively cheap biomass obtained from wastewater phycoremediation after anaerobic treatment (UASB) and to verify its potential in the control of weeds resistant to synthetic herbicides. The circular economy integration with an approach in bioherbicide production remains a new subject in the literature. To the best of our knowledge, this is the first study focused on that process that seeks to produce a closed cycle in the entire swine production chain, biogas energy generation, and recovery of raw material, resulting from the polishing of effluents for microorganism cultivation, aiming for the production of bioherbicides.

\section{MATERIALS AND METHODS}

\section{Microalgae Biomass and Fungal}

The microalgae used in this study derive from Chlorella spp. obtained from phycoremediation of swine wastewater, implemented at EMBRAPA Swine and Poultry (Concórdia, SC, Brazil). Microalgal biomass comprises $56.1 \%$ protein, $34.7 \%$ carbohydrate, $1.7 \%$ lipid, and $7.8 \%$ minerals. To produce the biocompound from microalgal biomass, we used the fungus Trichoderma koningiopsis, a microorganism isolated from Digitaria ciliares (Reichert Júnior et al., 2019). The microorganism's growth and maintenance occurred in Potato Dextrose Agar (PDA) and was maintained in a bacteriological greenhouse at $28^{\circ} \mathrm{C}$ for 7 days before the start of fermentation.

\section{Fermentation Process}

Preliminary tests were performed relating the biochemical composition of microalgae to the chemical composition of synthetic media optimized by Bordin et al. (2018), using microalgal biomass under different conditions: (1) raw biomass (with $89 \%$ humidity); (2) lyophilized biomass $\left(72 \mathrm{~h} ; 50^{\circ} \mathrm{C}\right.$ and vacuum pressure); (3) raw and lyophilized biomass pretreated with an ultrasound probe $(80 \%$ power, $10 \mathrm{~min}$ time and three pulses). Table 1 describes the composition and conditions used in the preliminary tests.

The fermentation medium was carried out in $300 \mathrm{ml}$ flasks with a useful volume of $150 \mathrm{ml}$ and sterilized in an autoclave for $20 \mathrm{~min}$ and $121^{\circ} \mathrm{C}$. After T. koningiopsis was inoculated with

TABLE 1 | Description of the preliminary tests.

\begin{tabular}{|c|c|c|}
\hline Assay & Microalgae & Description \\
\hline $\mathrm{F} 1$ & Raw & $33.3 \mathrm{~g} \mathrm{~L}^{-1}$ of microalgae $+T$. koningiopsis \\
\hline $\mathrm{F} 2$ & Raw & $\begin{array}{l}33.3 \mathrm{~g} \mathrm{~L}^{-1} \text { of microalgae pretreated with } \\
\text { ultrasound probe and } T \text {. koningiopsis }\end{array}$ \\
\hline F3 & Raw & $\begin{array}{l}66.6 \mathrm{~g} \mathrm{~L}^{-1} \text { of microalgae pretreated with } \\
\text { ultrasound probe and } T \text {. koningiopsis }\end{array}$ \\
\hline F4 & Raw & $66.6 \mathrm{~g} \mathrm{~L}^{-1}$ of microalgae $+T$. koningiopsis \\
\hline L1 & Lyophilized & $33.3 \mathrm{~g} \mathrm{~L}^{-1}$ of microalgae $+T$. koningiopsis \\
\hline L2 & Lyophilized & $\begin{array}{l}33.3 \mathrm{~g} \mathrm{~L}^{-1} \text { of microalgae pretreated with } \\
\text { ultrasound probe and } T \text {. koningiopsis }\end{array}$ \\
\hline L3 & Lyophilized & $\begin{array}{l}66.6 \mathrm{~g} \mathrm{~L}^{-1} \text { of microalgae pretreated with } \\
\text { ultrasound probe and } T \text {. koningiopsis }\end{array}$ \\
\hline L4 & Lyophilized & $66.6 \mathrm{~g} \mathrm{~L}^{-1}$ of microalgae $+T$. koningiopsis \\
\hline
\end{tabular}


approximately $10^{6}$ spores $\mathrm{m} \mathrm{L}^{-1}$. Fermentation was maintained on an orbital shaker at $28^{\circ} \mathrm{C}, 120 \mathrm{RPM}$ for $72 \mathrm{~h}$.

The final biomass (containing microalgae plus fungal mycelium) was determined using the dry cell mass method, expressed as grams of dry biomass per liter (Gern et al., 2008), and the liquid extract (filtered, named by this study as biocompound) was used for enzymatic quantification.

\section{Enzymatic Activities Quantification}

The quantification of amylase enzymes was based on the adapted methodologies of Fuwa (1954) and Pongsawadi and Yagisawa (1987). For cellulases, the filter paper was used as a hydrolysis substrate Ghose (1987). After enzymatic reactions, the release of reducing sugars was measured by the DNS (3,5 dinitrosalisylic acid) method of Miller (1959).

Quantitation of lipase was performed by preparing a 10\% (w $\left.\mathrm{v}^{-1}\right)$ olive oil and $5 \%\left(\mathrm{w} \mathrm{v}^{-1}\right)$ gum Arabic emulsion diluted a $90 \%\left(\mathrm{v} \mathrm{v}^{-1}\right) 100 \mathrm{mM}$ sodium phosphate buffer solution $\mathrm{pH} 6$. After the samples were subjected to agitation (165 RPM) for $32 \mathrm{~min}$ at $35^{\circ} \mathrm{C}$, lipase activity was determined through Equation 1 (Treichel et al., 2015).

$$
\mathrm{At}=\frac{(\mathrm{Aa}-\mathrm{Vb}) * \mathrm{MNaOH}}{\mathrm{t} * \mathrm{Vc}} * 1000
$$

Where: (Aa) mean of samples; $(\mathrm{Vb})$ control value; $(\mathrm{MNaOH})$ molarity of sodium hydroxide; $(\mathrm{t})$ reaction time; $(\mathrm{Vc})$ volume of extract used.

Peroxidases were quantified using the method proposed by Khan and Robinson (1994) and Devaiah and Shetty (2009). We added $1 \mathrm{~mL}$ of the fermented extract to the reaction medium and subjected to the thermostatic bath for $20 \mathrm{~min}$ at $35^{\circ} \mathrm{C}$. The final reaction was analyzed using a spectrophotometer at $470 \mathrm{~nm}$.

To determine laccase activity, the methodology proposed by $\mathrm{Hou}$ et al. (2004) was adapted using 2,2'-azino-di-(3ethylbenzothialozin-6-sulfonic) (ABTS) as the enzyme substrate. The reaction mixture contained $0.4 \mathrm{~mL}$ of ABTS $10 \mathrm{mM}$ and $3.4 \mathrm{~mL}$ of sodium acetate buffer $50 \mathrm{mM}, \mathrm{pH} 4.8$, and $0.2 \mathrm{~mL}$ of the enzyme extract and was subject to a thermostatic bath at $40^{\circ} \mathrm{C}$ for $5 \mathrm{~min}$. The samples were analyzed using a spectrophotometer at $420 \mathrm{~nm}$.

\section{Application of the Biocompounds Resistant Weed Leaf Surfaces}

The fermented biocompounds in the preliminary tests were evaluated for their bioherbicidal potential against weeds grown in a greenhouse. Leaf damage was evaluated after 7 and 15 days of treatment based on methodologies recommended by the Brazilian Weed Science Society (1995). The biocompound was applied using a brush because of the viscosity of the extract. The plants selected for the study included resistant to commercial herbicides: Bidens pilosa, Conyza bonariensis, Urochloa plantaginea, and Euphorbia heterophylla (Heap, 1999, 2019; Cerdeira et al., 2007; Dias et al., 2018).

\section{Germination Tests}

The activity of biocompounds was evaluated in the germination of seeds of the species Cucumis sativus. They were performed in previously disinfected Gerbox boxes and lined with Germitest ${ }^{\circledR}$ moistened with the respective treatment (biocompound produced), according to the Rules for Seed Analysis (Brazil, 2009). Four replications of 25 seeds were sown, totaling 100 seeds per treatment, conditioned in $\mathrm{BOD}$, at a constant temperature $\left(25^{\circ} \mathrm{C}\right)$, and a photoperiod of $12 / 12 \mathrm{~h}$ of light/dark.

We analyzed the number of germinated seeds and the number of seeds that germinated and became healthy plants for the germination test. The seeds were evaluated at 4,8 , and 10 days after the treatment, and we measured the hypocotyl and primary root length (plants with hypogeal germination). Germinated seeds are those grown to the top radicle of $2 \mathrm{~mm}$. Germination and vigor indices were calculated using Equations 2 and 3 , respectively.

$$
\text { (\%) } \mathrm{G}=\frac{\mathrm{ni} 1+\mathrm{ni} 2+\mathrm{ni} 3+\mathrm{ni} 4}{\mathrm{~A}} * 100
$$

Where, (ni) is the number of seeds germinated in each repetition and (A) is total seeds used.

$$
\text { Vigor index }=(\text { Hypocotyl }+ \text { Primary root }) *(\%) G
$$

\section{Statistical Analysis}

Analysis of variance (ANOVA) and the effect of variables were used to validate data using the tool Protimiza Experimental Design (Rodrigues and Iemma, 2014).

\section{RESULTS AND DISCUSSION}

\section{Enzyme Production and Substrate Interaction}

From the initial fermentation tests, we found that there was substantial production of peroxidases using lyophilized biomass. The ultrasonic pretreatment was not determinant for the production of this enzyme (Table 2 ). In comparison with the results found by Bordin et al. (2018), using a synthetic medium for the growth of the fungus, greater production of peroxidases is observed using microalgae biomass. For the other enzymes, the replacement of the synthetic medium by biomass was not promising.

Assay L4 was the largest producer of peroxidase and amylase (16.200 and $6.98 \mathrm{U} \mathrm{mL}^{-1}$, respectively). The assay L3 presented the highest cellulase and biomass production. Cellulose is the main carbohydrate in microalgae's cell wall and is prone to enzymatic degradation, whereas starch, the substrate of amylase, is found in plastids (intracellular) (Chu et al., 1982; Sander and Murthy, 2009; Velazquez-Lucio et al., 2018). The high biomass production may be linked to the higher substrate existence (66.6 g $\mathrm{L}^{-1}$ ) and also to the higher cellulase yields that break down the cellulose and generate a valuable substrate for fungal growth, the glucose.

Cellulase enzymes have three major components: (1) 1,4- $\beta$-D-glucan-glucanohydrolases (endoglucanases); (2) $1,4-\beta$-D-glucan-cellobiohydrolases and 1,4- $\beta$-D-glucan-glucanhydrolases (exoglucanases); (3) $\beta$-D-glucoside glucohydrolase ( $\beta$-glucosidases). The mechanisms of action on cellulose occur 
TABLE 2 | Enzymatic activity and biomass production of fermentative extracts using T. koningiopsis and microalgae raw and lyophilized under different conditions.

\begin{tabular}{|c|c|c|c|c|c|c|c|c|c|c|}
\hline \multirow[t]{2}{*}{ Conditions } & & \multicolumn{4}{|c|}{ Fresh microalgae } & \multicolumn{4}{|c|}{ Lyophilized microalgae } & \multirow{2}{*}{$\begin{array}{l}\text { Synthetic } \\
\text { medium* }\end{array}$} \\
\hline & & F1 & F2 & F3 & F4 & L1 & L2 & L3 & L4 & \\
\hline \multirow{3}{*}{$\begin{array}{l}\text { Enzymatic activity } \\
\left(\mathrm{U} \mathrm{mL}^{-1}\right)\end{array}$} & Peroxidase & $\mathrm{Nd}$ & $\mathrm{Nd}$ & 666.67 & 766.67 & 2966.70 & 133.30 & $15,400.00$ & $16,200.00$ & 41.00 \\
\hline & Cellulase & 0.50 & $\mathrm{Nd}$ & $\mathrm{Nd}$ & 0.25 & $\mathrm{Nd}$ & $\mathrm{Nd}$ & 3.99 & 5.99 & 10.62 \\
\hline & Amylase & $\mathrm{Nd}$ & $\mathrm{Nd}$ & 2.25 & $\mathrm{Nd}$ & $\mathrm{Nd}$ & $\mathrm{Nd}$ & $\mathrm{Nd}$ & 6.98 & 17.25 \\
\hline Biomass $\left(g \mathrm{~L}^{-1}\right)$ & & 2.26 & 2.09 & 4.78 & 4.75 & 11.44 & 13.21 & 14.31 & 14.05 & 1.85 \\
\hline
\end{tabular}

Nd, Not detected.

${ }^{*}$ Results of enzymatic production using synthetic media for growth of T. koningiopsis that represented the best bioherbicidal effect in $\mathrm{H}$. heterophylla (Bordin et al., 2018).

The composition of F1 tests; F2; F3; F4; L1; L2; L3; L4 is described in Table 1.

TABLE 3 | Phytotoxicity analysis on weeds after the 7th and 15th day of application of biocompounds F4 and L4 and comparison with studies carried out by Bordin et al. (2018), Reichert Júnior et al. (2019), and Camargo et al. (2019).

\begin{tabular}{|c|c|c|c|c|c|c|c|}
\hline Espécies & \multicolumn{7}{|c|}{ Responses do leaf damage in (\%) } \\
\hline Bidens pilosa & $\mathrm{Nd}$ & 1 & 5 & 5 & NA & $\mathrm{Nd}$ & 100 \\
\hline U. plantaginea & $\mathrm{Nd}$ & $\mathrm{Nd}$ & 5 & 5 & NA & $\mathrm{Nd}$ & NA \\
\hline
\end{tabular}

Biocompound F4, Obtained from fermentation with fresh microalgae; Biocompound L4, Obtained from fermentation with freeze-dried microalgae; NA, Not applied; Nd, Effect not detected.

in three stages: (1) endoglucanases break down non-covalent interactions within the crystalline structure of cellulose; (2) exoglucanases hydrolyze individual cellulose fibers into simple sugars, and cellobiohydrolases attack the ends of the chain, producing cellobiose; and (3) $\beta$-glucosidases release glucose monomers by hydrolyzing cellulose disaccharides and tetrasaccharides of cellulose (Li et al., 2009; Yeh et al., 2010; Harun and Danquah, 2011).

Amylase production was also found in the F3 and L4 assays suggesting that there is possibly a synergism between the peroxidase, lipase and cellulase enzymes in the breakdown of polysaccharides present in the microalgae cell wall, making available starch and other simpler carbohydrates that are present intracellularly (VelazquezLucio et al., 2018). Exogenous enzymes such as these have been linked to significant perturbation of microalgae cell walls, releasing nutrients with substantial nutritional value (Coelho et al., 2019).

Studies that analyzed the co-cultivation of microalgae with filamentous fungi in pelletizing processes, to remove microalgal cells from the liquid medium, found that microalgae cells were incorporated into the fungal hyphae mesh, with increased biomass production without a change in the composition of the microalgae lipids. The synergistic effect of biomass production and lipid accumulation is also due to the fungal utilization of carbohydrates in the microalgae cell wall (Xie et al., 2013).

\section{Application on Resistance Weeds}

The biocompounds obtained in the F4 and L4 assays showed better enzymatic responses, so they were applied to weeds to evaluate the phytotoxic effects through the biocompound, produced using the raw and lyophilized biomass. Table 3 presents the results of the phytotoxic damage found and compared with other studies in the literature. The percentage of effects were related to the control assay, which used only distilled water.

There was a selective effect on the weed Conyza bonariensis. That is a $100 \%$ phytotoxic effect within 15 days after applying the extract using raw microalgae biomass and fungus (Figure 1). This species can produce an excessive number of viable non-dormant seeds that can germinate and complete various life cycles in 1 


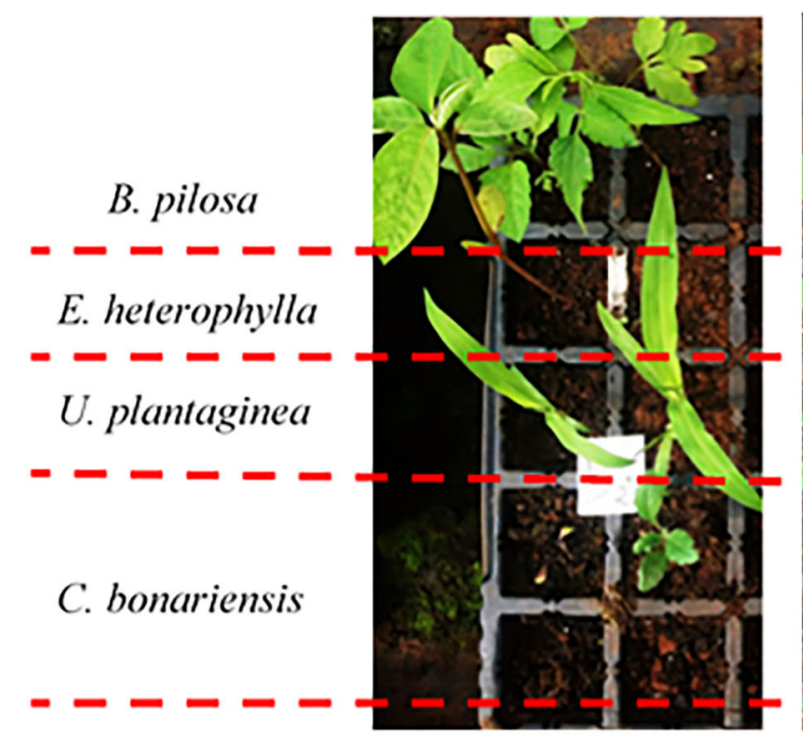

F4

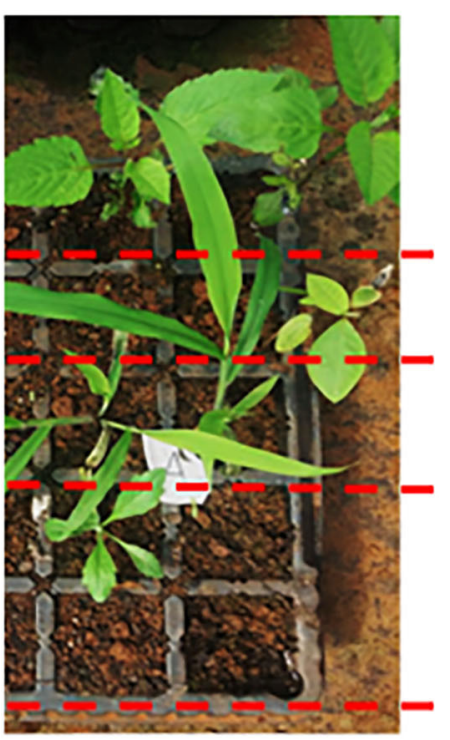

L4

FIGURE 1 | Illustration after the 15th day of treatment with the biocompound produced.

year, suggesting that their control is extremely important $(\mathrm{Wu}$ et al., 2007).

The phytotoxic effects after the 15 th day in C. bonariensis were greater with the use of biocompound produced from raw biomass in fermentation than lyophilized biomass. In addition to reducing costs with the microalgae drying process, these results are interesting because they suggest satisfactory control of a species that is considered highly resistant to conventional herbicides. Studies such as Hosseinizand et al. (2017) revealed that microalgae drying processes could produce adverse effects on Chlorella surface lipids' color, structure, and composition, and carbohydrates. In this case, these adverse effects may be influencing the excretion of enzymes and other bioactive metabolites in fermentation with $T$. koningiopsis and consequently altering the biocontrol characteristics in $C$. bonariensis between the two biocomposites.

Enzyme action has been described as a key mechanism to allow the entry of microorganisms and their compounds into the target plant, facilitating the access and dispersion of pathogens through the host (Reichert Júnior et al., 2019). They may be associated with virulence factors as they act in the degradation of the walls of plant cells, proteins and, lipid membranes (Cordeau et al., 2016). Several microorganisms have enzymes, and other bioactive secondary metabolites, that can combat or prevent chemical defense mechanisms of plants and regulate plant growth (Keen and Staskawicz, 1988; Vinale et al., 2008). Some strains of Trichoderma spp. are prolific enzyme producers, including those that degrade plant cell walls (Harman et al., 2004; Noll et al., 2016; Seppälä et al., 2017). The enzymes quantified in this study have been reported to be auxiliary agents attenuating of phytotoxic effects on plants during biological control because of their possible mechanisms of action on plants (Cordeau et al., 2016; Bordin et al., 2018; Reichert Júnior et al., 2019).

The effects of selectivity for Conyza bonariensis are related to possible compounds released by microalgae during enzymatic degradation. In the fermentation process, because the results of phytotoxicity in studies of $T$. koningiopsis for growth in commercial media (glucose, peptone, yeast extract, and other salts) were specific for the species Euphorbia heterophylla (Bordin et al., 2018; Reichert Júnior et al., 2019). Recently Coelho et al. (2019) found that the degradation of Chlorella vulgaris cell walls from an enzymatic pool generated the release of bioactive compounds such as proteins, saturated and monounsaturated fatty acids, amino acids and some types of carotenoids such as $\beta$-carotene, astaxanthin, canthaxanthin, and lutein, all of which have antioxidant activity (Gouveia et al., 2006). It was speculated that these compounds, along with the fungus metabolites, may exhibit certain types of selectivity as biocontrol agents in plants; however, the mechanism by which this occurs remains unclear.

In comparison with other studies presented in Table 3, promising results using the fungus T. koningiopsis were also found by Camargo et al. (2019) in B. pilosa, C. bonariensis, and E. heterophylla with up to $100 \%$ phytotoxicity. In the study, the authors presented an innovative solution combining synthetic herbicides (2,4-dichlorophenoxyacetic acid, glyphosate, and ammonium glufosinate) in fermentation with T. koningiopsis generating an effective compound with synergistic action between bioherbicides and synthetic herbicides in the control of the three plants. In the studies by Reichert Júnior et al. (2019), more promising results were found with the use of adjuvants and with a repeated application on target plants up to 8 times within 30 days. 
Some studies show that when exposed to stress conditions, plants produce a large number of reactive oxygen species (ROS). These substances oxidize and modify cellular components such as proteins, lipids, and nucleic acids, preventing them from performing their original functions. They are highly harmful at high concentrations. ROS regulates stomatal behavior, pathogen defenses, and various processes, including programmed cell death (Apel and Hirt, 2004; Mittler et al., 2004; Gill and Tuteja, 2010; Hoseini and Zargari, 2013; Schippers et al., 2016; Huang et al., 2019). One of the mechanisms used by plants to circumvent such a situation is based on enzymatic antioxidant defense systems (catalase, peroxidase, superoxide dismutase, glutathione reductase, etc.), and non-enzymatic systems that act synergistically and interactively to neutralize free radicals (Apel and Hirt, 2004; Benavides et al., 2005; Huang et al., 2019). When there is an imbalance in cells between elimination systems and ROS levels, the cells enter an oxidative state that can lead to death (Huang et al., 2019). High concentrations of the peroxidase enzyme in the biocompound formulation may cause stress symptoms in the plant because these enzymes act on the polysaccharide cell wall structure. The high percentage of phytotoxic effects in $C$. bonariensis suggest that there are increased levels of ROS interacting with the plant defense system, resulting in oxidative modification. It is also interesting to mention that Trichoderma has already been disclosed as a microorganism that increases defense-related plant enzymes production, including various peroxidases, chitinases, $\beta-1,3-$ glucanases as well as the lipoxygenase hydroperoxide-lyase pathway (Koike et al., 2001; Howell, 2003; Vinale et al., 2012). These findings, combined with the possible antioxidant products released by microalgae during fermentation, could explain the phytotoxic effects presented and the selectivity for $C$. bonariensis species.

\section{Analysis of Design of Experimental Responses}

The analysis of enzyme quantification during the biocompound production process is presented in numerous studies that relate the phytotoxic potential through the action of extracellular enzymes such as cellulases, peroxidases, lipases, amylases, etc. (Bordin et al., 2018; Camargo et al., 2019; Reichert Júnior et al., 2019). The conditions studied in the planning aim to explore enzymes' production resulting from the interaction between $T$. koningiopsis and microalgae biomass during the fermentation process. The investigated variables can modify the behavior of the microorganism in this unconventional substrate.One of the limitations to the industrial implementation of microorganisms isolated from the environment, as in T. koningiopsis, is that the product spectrum generally varies with thermodynamic expectations, even if the system is systematic and repeatable (Temudo et al., 2007). This limitation occurs mainly due to a lack of understanding of how operational factors affect the microbial community/functionality and, therefore, the product spectrum (Mohd-Zaki et al., 2016).

Previous studies showed that changes in fungal morphology could be influenced by medium composition, $\mathrm{pH}$, culture temperature, agitation, aeration, among others (Papagianni, 2004; Liao et al., 2007). Each factor mentioned has different importance for growth morphologies. For example, some strains of Rhizopus sp. require strong agitation, while strains such as Penicillium chrysogenum require high $\mathrm{pH}$ values (Metz and Kossen, 1997).

With the satisfactory results obtained using gross microalgal biomass in the initial tests, we decided to continue with this type of biomass in the experimental design. Because of the high production of peroxidases in the preliminary tests, we decided to analyze laccases activities. Table 4 presents the planning matrix and the answers obtained.

Trichoderma species such as $T$. harzianum have already demonstrated laccase production potential; temperature and $\mathrm{pH}$ effects during microorganism growth were important for enzyme production (Ranimol et al., 2018). The authors' maximum activity was $0.971 \mathrm{U}$ mL-1 after 12 days of incubation at $\mathrm{pH} 5.5$ and $30^{\circ} \mathrm{C}$ (Ranimol et al., 2018). Other studies reported that laccase activities were positive when there was an additional nitrogen source in the medium. Peptone and casein, two organic nitrogen sources, showed better laccase inducers than inorganic nitrogen sources (Mikiashvili et al., 2006; Bettin et al., 2009; Schneider et al., 2018). In the present study, no external nitrogen source was added, possibly explaining the low laccase yields. Nevertheless, the results obtained after $72 \mathrm{~h}$ of incubation with T. koningiopsis in microalgae biomass are promising compared to those found by Ranimol et al. (2018). The best activities were 12 days of fermentation under synthetic media.

\section{Statistical Analysis}

Using the Protimiza Experimental Design tool, the possible effects of the studied variables were analyzed, and their interaction in determining enzymatic activities and biomass production. Figure 2 presents the Pareto charts, with a statistical confidence of $95 \%$.

Amylase had a positive and significant effect on agitation $(p$ $<0.05)$. Table 3 displays the maximum amylase production in the highest agitation assays (200 RPM), suggesting that strong agitation facilitates starch availability inside the microalgal cell, as a substrate for amylase. The effect of agitation was also significant and positive for cellulase and peroxidase activities. However, it was significant and negative for biomass production. These results may suggest that high agitation produces a stress condition to the fungus, releasing enzymes into the liquid medium. The medium agitation influences the free enzymes in contact with the bioavailable substrate; they tend to favor the enzyme-substrate interaction mechanism, producing desirable effects for enzymatic production. Nevertheless, for laccase and lipase, no physical parameters were statistically significant, suggesting that a deeper analysis on the interaction of the filamentous fungi with the microalgae in fermentation processes should be undertaken, since it was already seen that during the interaction there was no lipid consumption (Xie et al., 2013).

Using analysis of variance, we found that only the cellulase response had its model validated with 95\% confidence; $\mathrm{F}$ 
TABLE 4 | Matrix of experimental design central composite rotatable design (CCRD) $2^{3}$ (coded and real values) and respective answers in terms of enzymatic and biomass production.

\begin{tabular}{|c|c|c|c|c|c|c|c|c|c|}
\hline \multicolumn{4}{|c|}{ Conditions } & \multicolumn{5}{|c|}{ Enzymatic activities* } & \multirow[t]{2}{*}{ Biomass } \\
\hline Assay & Temperature $\left({ }^{\circ} \mathrm{C}\right)$ & Agitation (RPM) & $\mathrm{pH}$ & Amylase & Cellulase & Lipase & Peroxidase & Laccase & \\
\hline E1 & $-1(26.1)$ & $-1(40.5)$ & $-1(5.2)$ & 0.00 & 0.000 & 0.00 & 50.00 & 0.060 & 5.70 \\
\hline E2 & $1(44)$ & $-1(40.5)$ & $-1(5.2)$ & 0.17 & 0.048 & 0.90 & 274.33 & 0.017 & 4.26 \\
\hline E3 & $-1(26.1)$ & $1(160)$ & $-1(5.2)$ & 0.17 & 0.051 & 0.00 & 381.33 & 0.009 & 4.34 \\
\hline E4 & $1(44)$ & $1(160)$ & $-1(5.2)$ & 0.15 & 0.087 & 2.30 & 612.67 & 0.029 & 4.09 \\
\hline E5 & $-1(26.1)$ & $-1(40.5)$ & $1(11.7)$ & 0.00 & 0.000 & 0.00 & 340.00 & 0.025 & 3.35 \\
\hline E6 & $1(44)$ & $-1(40.5)$ & $1(11.7)$ & 0.11 & 0.064 & 0.00 & 403.00 & 0.020 & 4.47 \\
\hline E7 & $-1(26.1)$ & $1(160)$ & $1(11.7)$ & 0.16 & 0.097 & 0.55 & 556.00 & 0.024 & 4.18 \\
\hline E8 & $1(44)$ & $1(160)$ & $1(11.7)$ & 0.19 & 0.146 & 1.90 & 818.33 & 0.040 & 2.99 \\
\hline E9 & $-1.68(20)$ & $0(100)$ & $0(8.5)$ & 0.20 & 0.080 & 1.70 & 460.33 & 0.006 & 4.47 \\
\hline E10 & $1.68(50)$ & $0(100)$ & $0(8.5)$ & 0.08 & 0.056 & 2.05 & 135.67 & 0.00 & 4.39 \\
\hline E11 & $0(35)$ & $-1.68(0)$ & $0(8.5)$ & 0.05 & 0.026 & 2.50 & 73.33 & 0.00 & 5.11 \\
\hline E12 & $0(35)$ & $1.68(200)$ & $0(8.5)$ & 0.21 & 0.115 & 4.90 & 725.33 & 0.029 & 3.75 \\
\hline E13 & $0(35)$ & $0(100)$ & $-1,68(3.0)$ & 0.00 & 0.00 & 0.00 & 156.67 & 0.055 & 4.66 \\
\hline E14 & $0(35)$ & $0(100)$ & $1,68(14)$ & 0.00 & 0.00 & 0.00 & 550.00 & 0.00 & 2.87 \\
\hline E15 & $0(35)$ & $0(100)$ & $0(8.5)$ & 0.00 & 0.00 & 1.20 & 528.00 & 0.068 & 4.01 \\
\hline E16 & $0(35)$ & $0(100)$ & $0(8.5)$ & 0.00 & 0.00 & 0.90 & 566.00 & 0.067 & 4.28 \\
\hline E17 & $0(35)$ & $0(100)$ & $0(8.5)$ & 0.00 & 0.00 & 0.00 & 466.67 & 0.065 & 4.15 \\
\hline
\end{tabular}

*Activities presented in $U \mathrm{~mL}^{-1}$.

calculated: 5.1 and $R^{2}: 86.66 \%$ (Equation 4 ).

$$
\begin{aligned}
\text { Cellulase }= & 0+0.01 \mathrm{x}_{1}+0.03 \mathrm{x}_{1}^{2}+0.03 \mathrm{x}_{2}+0.03 \mathrm{x}_{2}^{2}+0.01 \mathrm{x}_{3} \\
& +0.01 \mathrm{x}_{2} \mathrm{x}_{3}
\end{aligned}
$$

The variables presented $(\mathrm{x} 1, \mathrm{x} 2$, and $\mathrm{x} 3)$ refer to the conditions described in the legend of Figure 2.

\section{Germination Analysis in Cucumis sativus}

The biocompounds produced in the experimental planning were applied and analyzed against seed pre-germination (Table 5). Generally, Cucumber species are used as model plants because they are susceptible and are considered good bioindicators (Redda et al., 2018; Todero et al., 2018). Table 5, together with Figure 3, shows the results found 8 days after the application the biocompound in the $C$. sativus seeds.

The bioherbicidal effect has been demonstrated for some of the biocompounds evaluated in C. sativus. A particular case was the germination inhibition result for test E14. No hypocotyl and primary root measurements or vigor indices were observed. Non-germination is explained by the high $\mathrm{pH}$ (14). A positive control with water at $\mathrm{pH} 14$ was performed, and no germination rate was recorded (Figure 4). Even with promising effects, it is not the objective of this work to generate a biocompound with bioherbicidal effects at $\mathrm{pH} 14$, because in real applications, the use of a bioherbicidal agent at such high $\mathrm{pH}$ could have undesirable consequences for other cultures, microorganisms, and even for the environment. The justification for having analyzed such an extreme range was to investigate the microorganisms' performance involved in the fermentation process and its concomitant enzyme production.

Other results of germination rates showed no inhibitory effect on C.sativus. Results lower than $100 \%$ of germination are attributed to repetitions between 23 and 24 seeds, germinated in the Gerbox. Thereby generating $98 \%$ germination rates for E1 and E5, and 99\% for E9 and E10.The main data to be interpreted are represented by the control with seeds soaked only with distilled water, which still did not show the best results, suggesting that some biocompounds can assist in plant development. Nevertheless, we observed changes in some plants' growth that suffered some retardation of their physiological development (Table 5).

Some treatments showed an effect on the plants' deficiency. Even presenting root and hypocotyl development, they contained fragile physical structures that were very sensitive to any contact. Examples are plants that have been treated with biocompounds E2 (Figure 5A), E11 and E16.

Plants that were in contact with biocompound E11, for example, also presented a reduction in the hypocotyl development (averages of $37.37 \mathrm{~mm}$ ) (Figure 5B). The same occurred with plants exposed to the biocompound E16 (Figure 5C). Also, demonstrating developmental deficiencies and breaking sensitivity had a low hypocotyl length of only $32.56 \mathrm{~mm}$ and $30.03 \mathrm{~mm}$ root. 

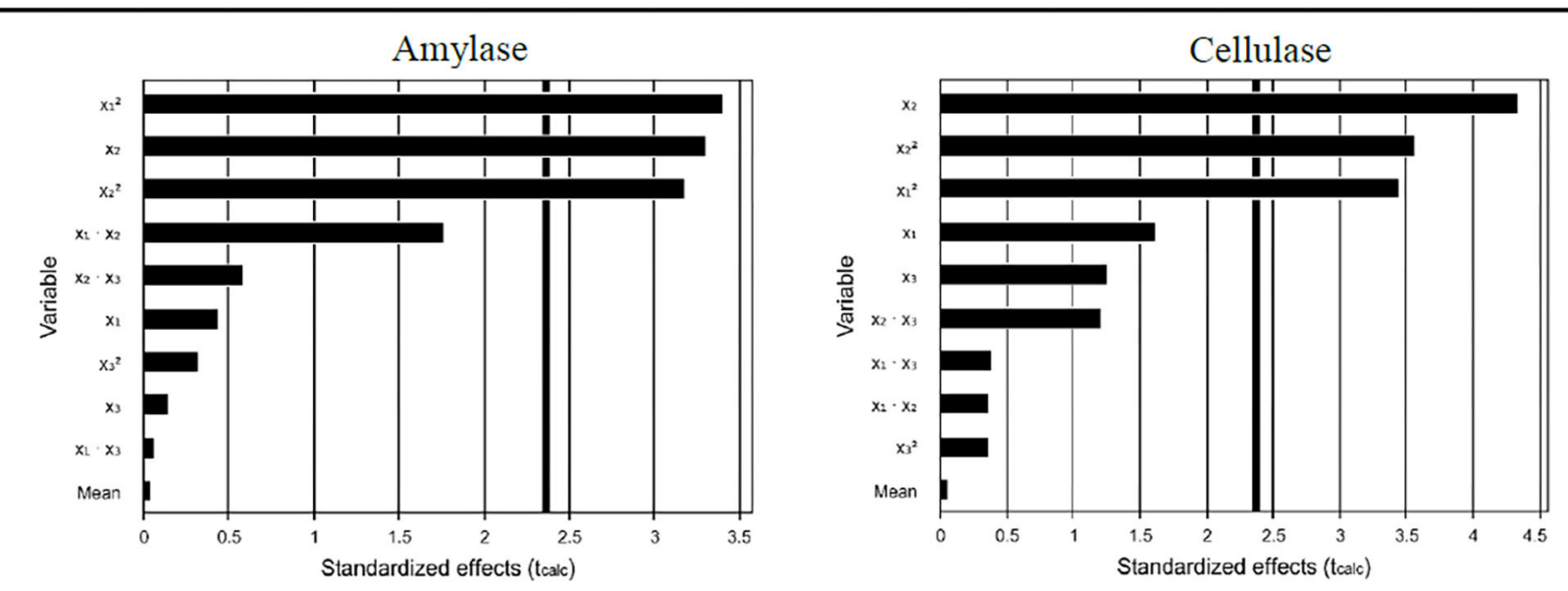

Lipase

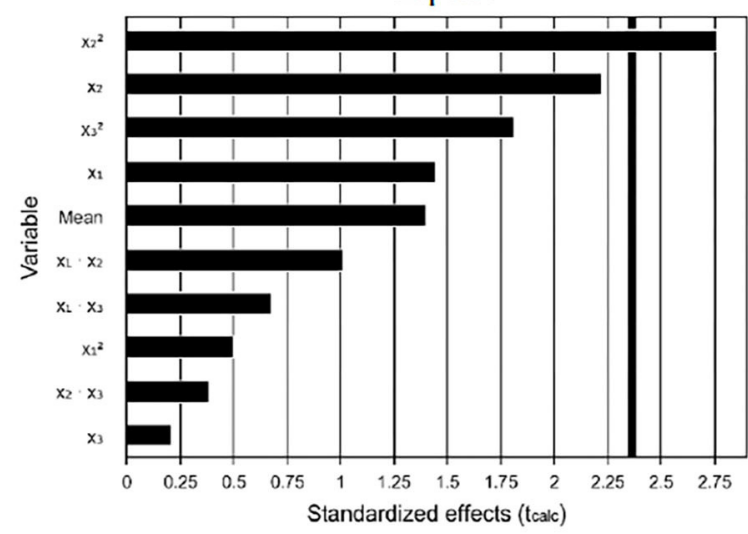

Laccase

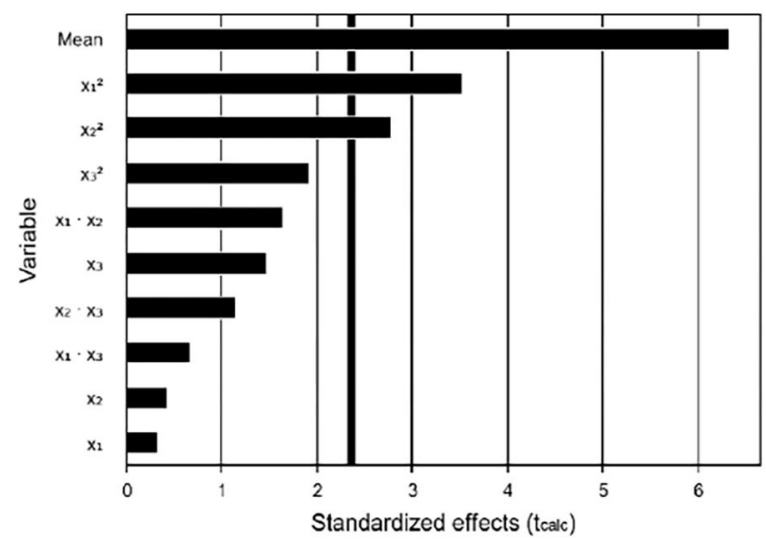

Peroxidase

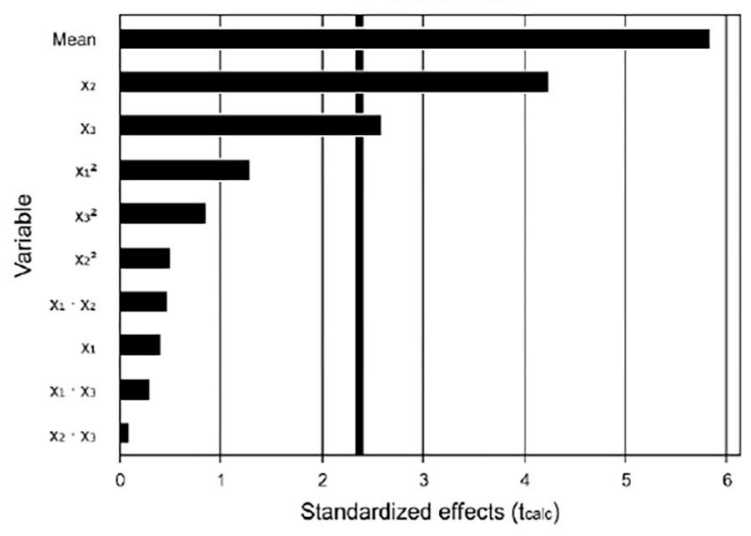

Biomass

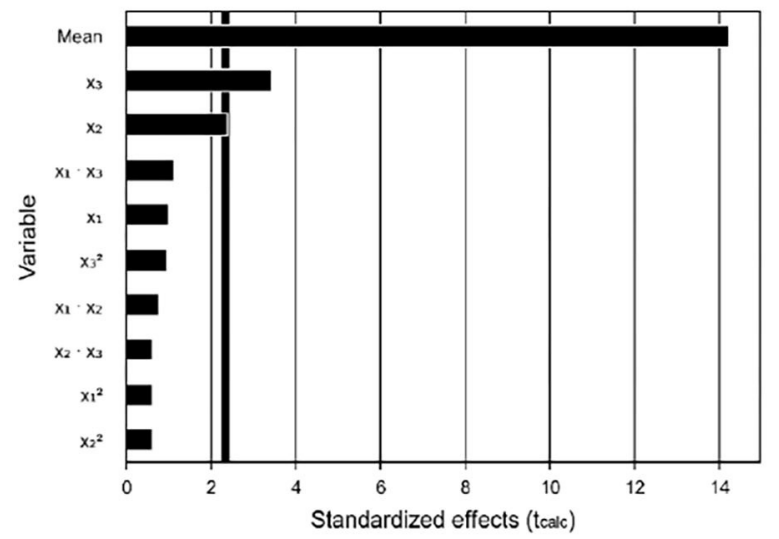

Legend:

$x 1$ : Temperature $\left({ }^{\circ} \mathrm{C}\right) ; \quad x 2:$ Agitation $(\mathrm{RPM}) ; \quad x 3: \mathrm{pH}$

FIGURE 2 | Pareto graph showing the influence of three variables in enzyme activity determination and biomass production. 
TABLE 5 | Germination tests in Cucumis sativus seeds with liquid biocompounds produced in design of experiments (CCRD $\left.2^{3}\right)$ after 8 days of application.

\begin{tabular}{|c|c|c|c|c|c|c|c|}
\hline & $\% \mathbf{G}$ & $\begin{array}{c}\sigma \\
\% \mathbf{G}\end{array}$ & $\begin{array}{c}\text { Hypocotyl } \\
\text { (mm) }\end{array}$ & $\begin{array}{c}\sigma \\
\text { Hypocotyl }\end{array}$ & $\begin{array}{l}\text { Root } \\
(\mathrm{mm})\end{array}$ & $\begin{array}{c}\sigma \\
\text { Root }\end{array}$ & $\begin{array}{l}\text { Vigor } \\
\text { index }\end{array}$ \\
\hline Witness & $100 \%$ & \pm 0 & 44.27 & \pm 2.80 & 66.59 & \pm 8.94 & 110.86 \\
\hline E1 & $98 \%$ & $\pm 0,57$ & 2.51 & \pm 3.64 & 5.70 & \pm 2.21 & 8.05 \\
\hline E2 & $100 \%$ & \pm 0 & 46.78 & \pm 2.53 & 60.12 & \pm 16.63 & 106.90 \\
\hline E3 & $100 \%$ & \pm 0 & 33.14 & \pm 5.21 & 34.40 & \pm 2.53 & 67.55 \\
\hline E4 & $100 \%$ & \pm 0 & 39.22 & \pm 2.73 & 61.12 & \pm 21.49 & 100.35 \\
\hline E5 & $98 \%$ & $\pm 0,57$ & 42.88 & \pm 7.12 & 50.74 & \pm 24.80 & 91.75 \\
\hline E6 & $100 \%$ & \pm 0 & 64.64 & \pm 10.99 & 64.78 & \pm 13.88 & 129.42 \\
\hline E7 & $100 \%$ & \pm 0 & 58.28 & \pm 16.23 & 63.33 & \pm 8.57 & 121.61 \\
\hline E8 & $100 \%$ & \pm 0 & 55.36 & \pm 1.45 & 57.82 & \pm 29.63 & 113.18 \\
\hline E9 & $99 \%$ & $\pm 0,5$ & 4.16 & \pm 1.25 & 18.26 & \pm 3.166 & 22.20 \\
\hline E10 & $100 \%$ & \pm 0 & 35.23 & \pm 5.28 & 43.40 & \pm 10.90 & 78.64 \\
\hline E11 & $99 \%$ & $\pm 0,5$ & 37.37 & \pm 6.58 & 45.14 & \pm 24.70 & 81.69 \\
\hline E12 & $100 \%$ & \pm 0 & 44.79 & \pm 3.45 & 97.03 & \pm 11.75 & 141.80 \\
\hline E13 & $100 \%$ & \pm 0 & - & - & 10.90 & \pm 4.47 & - \\
\hline E14 & $0 \%$ & \pm 0 & - & - & - & - & - \\
\hline E15 & $100 \%$ & \pm 0 & 37.57 & \pm 6.26 & 30.84 & \pm 7.98 & 68.42 \\
\hline E16 & $100 \%$ & \pm 0 & 32.56 & \pm 3.56 & 30.03 & \pm 2.73 & 62.59 \\
\hline E17 & $100 \%$ & \pm 0 & 37.24 & \pm 4.79 & 66.30 & \pm 11.33 & 103.55 \\
\hline
\end{tabular}

$\sigma=S D ; \%$ G, Germination percentage at 8 days after application of the biocompounds; Root, Primary root measured 10 days after biocompound application.

Thus, the results presented in Table 5 show that the treatments were efficient for the germination of seeds exposed to the $2.51 \mathrm{~mm}$ of E1 biocompound. For the development of hypocotyl and $5.70 \mathrm{~mm}$ primary root (Figure 5D). For the $4.16 \mathrm{~mm}$ E9 biocompound for hypocotyl development and $18.26 \mathrm{~mm}$ root (Figure 5E). The E13 biocompound showed no hypocotyl development but roots with $10.90 \mathrm{~mm}$ (Figure 5F). It is also noteworthy that although the E7 biocompound produced adequate hypocotyl, with $58.28 \mathrm{~mm}$. The primary root length of $63.33 \mathrm{~mm}$, its root system, was very thin with a set of deficient and sensitive roots (Figure 5G). The same happens with biocompound E15 that, in addition to having fragile roots, showed deficiencies in its leaf development (Figure 5H).

Colonization of Trichoderma spp., in plant roots, caused metabolic changes and pathogenesis-related protein activations. That induced more excellent plant resistance to subsequent attack by numerous microbial pathogens (Vinale et al., 2012).

Although in this study, satisfactory analyses were observed in terms of germination rates of C. sativusseeds (Table 5), we found that all biocompounds affected plant morphology after 8 days of application (Figure 2). The genetic approach and opposition to the physiological investigations carried out in this study could explain the morphological changes that occurred during the plant after germination. This approach could elucidate the enzymes' effects during the development stage since the germination rates and the vigor index consider only physiological parameters. ROS has been found to interact with epigenetic modifiers and hormones that influence various genes' expression and control plant development processes (Gill and Tuteja, 2010; Zeng et al., 2017; Kong et al., 2018).
In this work, we focused on "minimizing costs" in the context of the bioprocess to formulate a biocompound with potential bioherbicide. The biomass of microalgae grown in swine wastewater proved to be a potential source of nutrients. Large-scale production would not be a challenging issue in countries where pig production is abundant. In the fermentative process, biomass can be used in fresh form, without the need for freeze-drying and pre-treatment, thus reducing two unit operations in the process that would directly affect an industrial scale study. It was not necessary to use commercial means and external addition of nutrients for this microorganism. Also, thinking about expanding scale would be a great challenge to overcome as many fungal bioherbicides, seen during this work, use commercial growth media. The investigated parameters of fermentation, such as agitation, temperature, and $\mathrm{pH}$, could be easily adjusted in a bioreactor thinking at an industrial level, without requiring complex investments.

\section{CONCLUSION}

Satisfactory biocontrol and selection results were obtained during preemergence for model plants (Cucumis sativus) and C. bonariensis with synergistic effects of secondary metabolites and enzymes produced during the fermentation stage. Responses with up to $100 \%$ phytotoxicity were found. The influence of various enzymes can produce stress conditions on the leaf surface of the target plant as well as on the vigor index and morphological characteristics of the seeds. This suggests that the biocompound can be used for pre- and post-emergency control, ensuring greater environmental and food safety. 

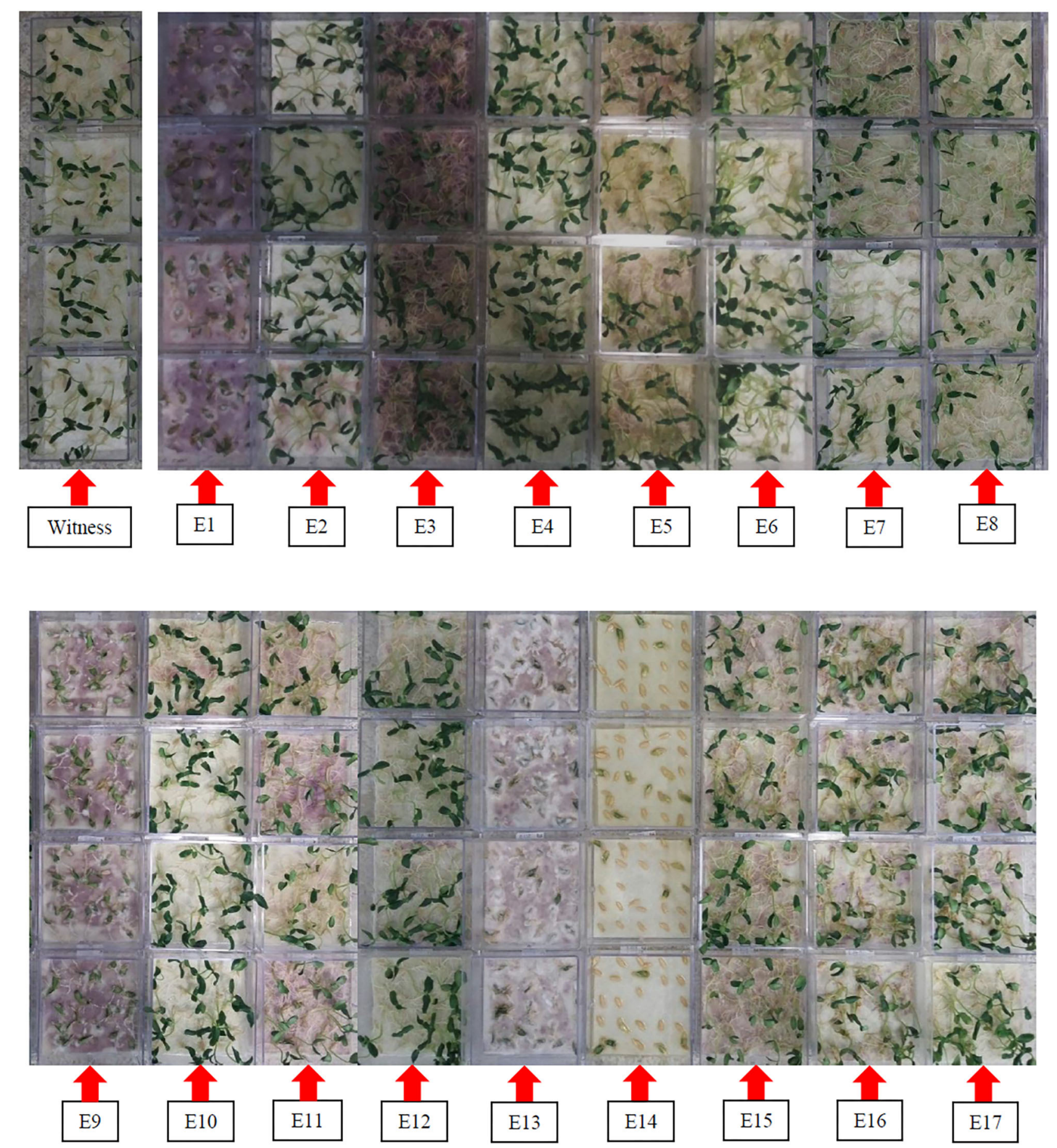

FIGURE 3 | Results of the application of biocompounds produced in pre-emergence of Cucumis sativus.

Bioherbicides can be a more suitable and environmentally friendly alternative to commercial herbicides to achieve sustainability in agriculture (Cordeau et al., 2016; Frumi Camargo et al., 2020). Nevertheless, several challenges are overcome, including weed resistance and high production costs with the acquisition of raw material, process factors, the addition of adjuvants, application repetitions, etc. The integration of the circular economy concept in biotechnological processes served in this study as a strategy to minimize the costs in the production process of a biocompound. The use of biomass produced from 

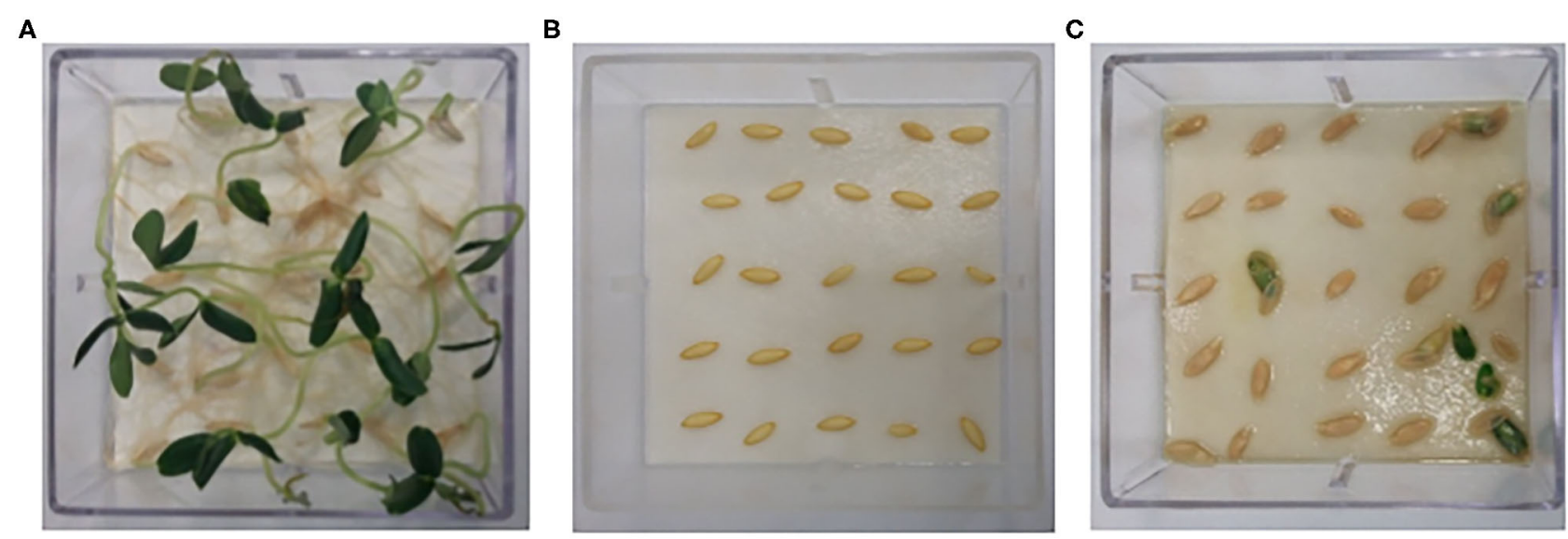

FIGURE 4 | Germination analysis: (A) Negative control with distilled water; (B) Positive control with water at pH; (C) Test E14.
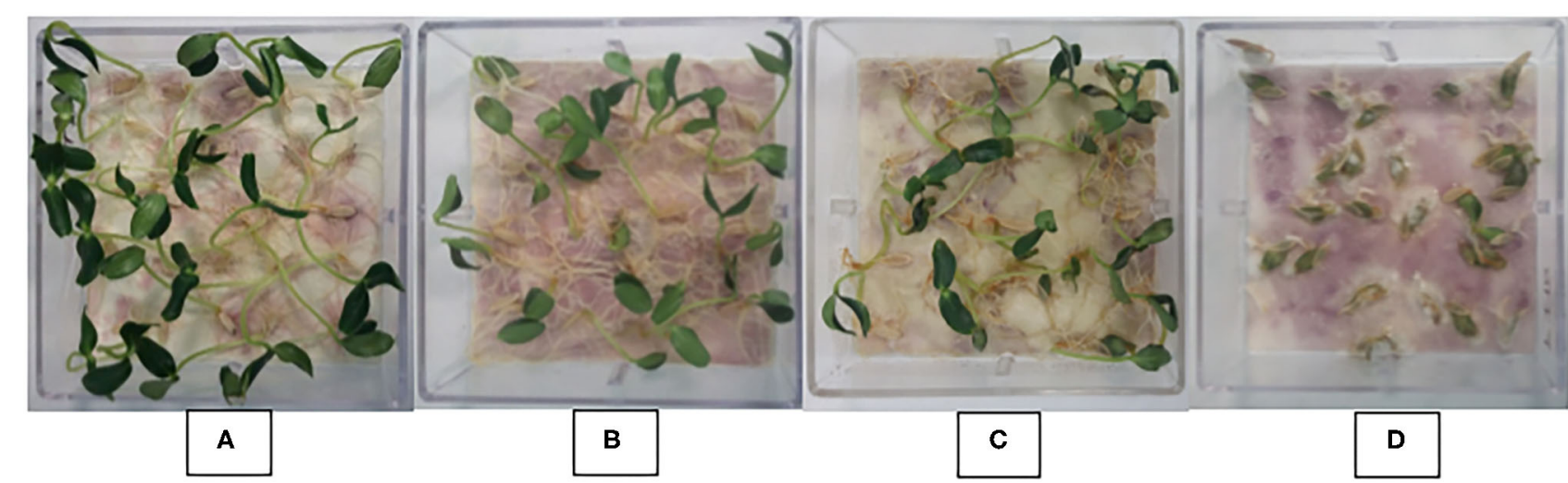

D

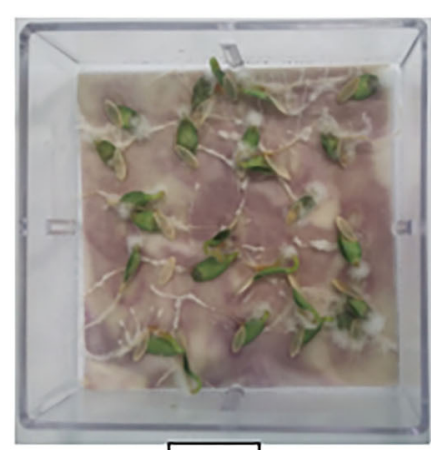

E

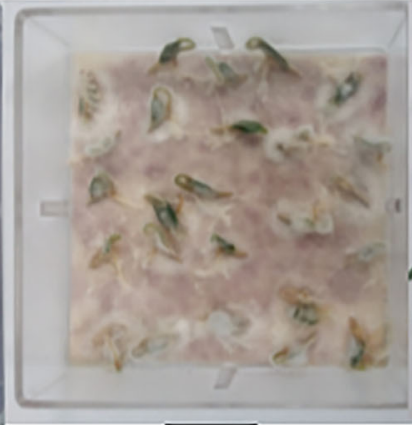

$\mathbf{F}$
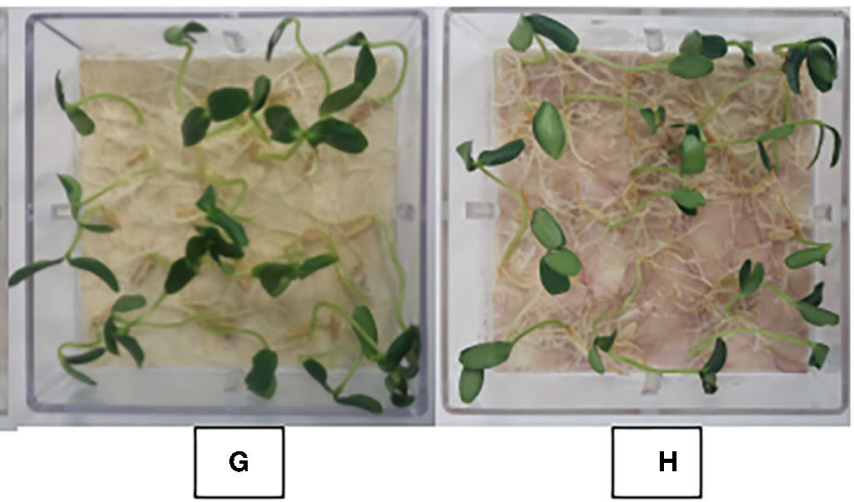

FIGURE 5 | Visualization of the growth of biocompounds that presented satisfactory results of bioherbicidal effect in Cucumis sativus. (A) Biocompound E2; (B) Biocompound E11; (C) Biocompound E16; (D) Biocompound E1; (E) Biocompound E9; (F) Biocompound E13; (G) Biocompound E7; (H) Biocompound E15.

industrial processes is a form of polishing effluents from to produce the relatively cheap raw material. The use of these products in fermentation processes benefit the environment, beyond the valorization of raw material.

\section{DATA AVAILABILITY STATEMENT}

The datasets generated for this study are available on request to the corresponding author. 


\section{AUTHOR CONTRIBUTIONS}

FSS, AFC, TS, CB, BV, SNW, CU, CC, and AU: experimental procedures, results discussion, and data treatment. WM, HMS, AM, GF, AJM, and HT: research coordinators.

\section{REFERENCES}

Apel, K., and Hirt, H. (2004). Reactive oxygen species: metabolism, oxidative stress, and signal transduction. Annu. Rev. Plant Biol. 55, 373-399. doi: 10.1146/annurev.arplant.55.031903.141701

Appleby, A. P., Müller, F., and Carpy, S. (2000). Ullmann's Encyclopedia of Industrial Chemistry. New Jersey: Wiley.

Benavides, M. P., Gallego, S. M., and Tomaro, M. L. (2005). Cadmium toxicity in plants. Brazilian J. Plant Physiol. 17, 21-34. doi: 10.1590/S1677-04202005000100003

Bettin, F., Montanari, Q., Calloni, R., Gaio, T. A., Silveira, M. M., and Dillon, A. J. P. (2009). Production of laccases in submerged process by Pleurotus sajor-caju PS2001 in relation to carbon and organic nitrogen sources, antifoams and Tween 80. J. Ind. Microbiol. Biotechnol. 36, 1-9. doi: 10.1007/s10295-008-0463-1

Bordin, E. R., Frumi Camargo, A., Rossetto, V., Scapini, T., Modkovski, T. A., Weirich, S., et al. (2018). Non-toxic bioherbicides obtained from trichoderma koningiopsis can be applied to the control of weeds in agriculture crops. Ind. Biotechnol. 14, 157-163. doi: 10.1089/ind.2018.0007

Boyette, C. D., and Hoagland, R. E. (2015). Bioherbicidal potential of Xanthomonas campestris for controlling Conyza canadensis. Biocontrol Sci. Technol. 25, 229-237. doi: 10.1080/09583157.2014.966650

Brazil (2009). Seed analysis rules. Minist. Agric. Livest. Supply. 1, 18-398.

Brazilian Weed Science Society (1995). Procedures for Installation, Evaluation and Analysis of Experiments with Herbicides (Londrina, PR).

Camargo, A. F., Stefanski, F. S., Scapini, T., Weirich, S. N., Ulkovski, C., Carezia, C., et al. (2019). Resistant weeds were controlled by the combined use of herbicides and bioherbicides. Environ. Qual. Manag. 29, 37-42. doi: 10.1002/tqem.21643

Cerdeira, A. L., Gazziero, D. L. P., Duke, S. O., Matallo, M. B., and Spadotto, C. A. (2007). Review of potential environmental impacts of transgenic glyphosate-resistant soybean in Brazil. J. Environ. Sci. Heal. B 42, 539-549. doi: 10.1080/03601230701391542

Chu, F.-L. E., Dupuy, J. L., and Webb, K. L. (1982). Polysaccharide composition of five algal species used as food for larvae of the American oyster, Crassostrea virginica. Aquaculture 29, 241-252. doi: 10.1016/0044-8486(82)90138-7

Coelho, D., Lopes, P. A., Cardoso, V., Ponte, P., Brás, J., Madeira, M. S., et al. (2019). Novel combination of feed enzymes to improve the degradation of Chlorella vulgaris recalcitrant cell wall. Sci. Rep. 9:5382. doi: 10.1038/s41598-019-41775-0

Cordeau, S., Triolet, M., Wayman, S., Steinberg, C., and Guillemin, J. P. (2016). Bioherbicides: Dead in the water? a review of the existing products for integrated weed management. Crop Prot. 87, 44-49. doi: 10.1016/j.cropro.2016.04.016

De, A., Bose, R., Kumar, A., and Mozumdar, S. (2014). Targeted Delivery of Pesticides using Biodegradable Polymeric Nanoparticles. New Delhi: Springer Nature.

DEC (Department of Environment and Conservation) (2006). Department of Environment and Conservation (NSW). Hurstville, NSW.

Devaiah, S. P., and Shetty, H. S. (2009). Purification of an infection-related acidic peroxidase from pearl millet seedlings. Pestic. Biochem. Physiol. 94, 119-126. doi: 10.1016/j.pestbp.2009.04.010

Dias, M. F., Krenchinski, F. H., Pereira, V. G. C., Moreno, G., Albrecht, L. P., and Albrecht, A. J. P. (2018). Phytosociological survey of weeds in glyphosate resistant and susceptible soybean cultivation areas. Rev. Bras. Ciências Agrárias Brazil. J. Agric. Sci. 13, 1-7. doi: 10.5039/agraria.v13i4a5592

Drumm, F. C., Grassi, P., Georgin, J., Tonato, D., Pfingsten Franco, D. S., Chaves Neto, J. R., et al. (2019). Potentiality of the Phoma sp. inactive fungal biomass, a waste from the bioherbicide production, for the treatment of colored effluents. Chemosphere 235, 596-605. doi: 10.1016/j.chemosphere.2019.06.169

Frumi Camargo, A., Venturin, B., Bordin, E. R., Scapini, T., Spitza Stefanski, F., Klanovicz, N., et al. (2020). A low-genotoxicity bioherbicide obtained

\section{ACKNOWLEDGMENTS}

The authors thank CAPES, CNPq, and FAPERGS for the financial support for this study and EMBRAPA for the partnership.

from trichoderma koningiopsis fermentation in a stirred-tank bioreactor. Ind. Biotechnol. 16, 176-181. doi: 10.1089/ind.2019.0024

Fuwa, H. (1954). A new method for microdetermination of amylase activity by the use of amylose as the substrate. J. Biochem. 41, 583-603. doi: 10.1093/oxfordjournals.jbchem.a126476

Gern, R. M. M., Wisbeck, E., Rampinelli, J. R., Ninow, J. L., and Furlan, S. A. (2008). Alternative medium for production of Pleurotus ostreatus biomass and potential antitumor polysaccharides. Bioresour. Technol. 99, 76-82. doi: 10.1016/j.biortech.2006.11.059

Ghose, T. K. (1987). Measurement of cellulase activities. Pure Appl. Chem. 59, 257-268. doi: 10.1351/pac198759020257

Gill, S. S., and Tuteja, N. (2010). Reactive oxygen species and antioxidant machinery in abiotic stress tolerance in crop plants. Plant Physiol. Biochem. 48, 909-930. doi: 10.1016/j.plaphy.2010. 08.016

Gouveia, L., Raymundo, A., Batista, A. P., Sousa, I., and Empis, J. (2006). Chlorella vulgaris and Haematococcus pluvialis biomass as colouring and antioxidant in food emulsions. Eur. Food Res. Technol. 222, 362-367. doi: 10.1007/s00217-005-0105-z

Harman, G. E., Howell, C. R., Viterbo, A., Chet, I., and Lorito, M. (2004). Trichoderma species - opportunistic, avirulent plant symbionts. Nat. Rev. Microbiol. 2, 43-56. doi: 10.1038/nrmicro797

Harun, R., and Danquah, M. K. (2011). Enzymatic hydrolysis of microalgal biomass for bioethanol production. Chem. Eng. J. 168, 1079-1084. doi: 10.1016/j.cej.2011.01.088

Heap, I. (2019). The International Survey of Herbicide Resistant Weeds. Available online at: www.weedscience.org (accessed October 8, 2020).

Heap, I. M. (1999). The occurrence of herbicideresistant weeds worldwide. Pestic. Sci. 51, 235-243. doi: 10.1002/(SICI)1096-9063(199711)51:3<235::AID-PS649>3.0.CO;2-N

Hoseini, S. M., and Zargari, F. (2013). Cadmium in plants: a review. Int. J. Farming Allied Sci. 2, 579-581.

Hosseinizand, H., Sokhansanj, S., and Lim, C. J. (2017). Studying the drying mechanism of microalgae Chlorella vulgaris and the optimum drying temperature to preserve quality characteristics. Dry. Technol. 36, 1049-1060. doi: 10.1080/07373937.2017.1369986

Hou, H., Zhou, J., Wang, J., Du, C., and Yan, B. (2004). Enhancement of laccase production by Pleurotus ostreatus and its use for the decolorization of anthraquinone dye. Process Biochem. 39, 1415-1419. doi: 10.1016/S0032-9592(03)00267-X

Howell, C. (2003). Mechanisms employed by trichoderma species in the biological control of plant diseases: the history and evolution of current concepts. Plant Dis. 87, 4-10. doi: 10.1094/PDIS.2003.87.1.4

Huang, H., Ullah, F., Zhou, D.-X., Yi, M., and Zhao, Y. (2019). Mechanisms of ROS regulation of plant development and stress responses. Front. Plant Sci. 10:800. doi: 10.3389/fpls.2019.00800

Keen, N. T., and Staskawicz, B. (1988). Host range determinants in plant pathogens and symbionts. Annu. Rev. Microbiol. 42, 421-440. doi: 10.1146/annurev.mi.42.100188.002225

Khan, A. A., and Robinson, D. S. (1994). Hydrogen donor specificity of mango isoperoxidases. Food Chem. 49, 407-410. doi: 10.1016/0308-8146(94)90013-2

Koike, N., Hyakumachi, M., Kageyama, K., Tsuyumu, S., and Doke, N. (2001). Induction of systemic resistance in cucumber against several diseases by plant growth-promoting fungi: lignification and superoxide generation. Eur. J. Plant Pathol. 107, 523-533. doi: 10.1023/A:1011203826805

Kong, X., Tian, H., Yu, Q., Zhang, F., Wang, R., Gao, S., et al. (2018). PHB3 maintains root stem cell niche identity through ROS-responsive AP2/ERF transcription factors in Arabidopsis. Cell Rep. 22, 1350-1363. doi: 10.1016/j.celrep.2017.12.105 
Li, X., Yang, H., Roy, B., Wang, D., Yue, W., Jiang, L., et al. (2009). The most stirring technology in future: cellulase enzyme and biomass utilization. African J. Biotechnol. 8, 2418-2422.

Liao, W., Liu, Y., Frear, C., and Chen, S. (2007). A new approach of pellet formation of a filamentous fungus - Rhizopus oryzae. Bioresour. Technol. 98, 3415-3423. doi: 10.1016/j.biortech.2006.10.028

Metz, B., and Kossen, N. W. F. (1997). The growth of molds in the form of pellets-a literature review. Biotechnol. Bioeng. 19, 781-799. doi: 10.1002/bit.260190602

Michelon, W., Da Silva, M. L. B., Mezzari, M. P., Pirolli, M., Prandini, J. M., and Soares, H. M. (2016). Effects of nitrogen and phosphorus on biochemical composition of microalgae polyculture harvested from phycoremediation of piggery wastewater digestate. Appl. Biochem. Biotechnol. 178, 1407-1419. doi: 10.1007/s12010-015-1955-x

Mikiashvili, N., Wasser, S. P., Nevo, E., and Elisashvili, V. (2006). Effects of carbon and nitrogen sources on Pleurotus ostreatus ligninolytic enzyme activity. World J. Microbiol. Biotechnol. 22, 999-1002. doi: 10.1007/s11274-006-9132-6

Miller, G. L. (1959). Use of dinitrosalicylic acid reagent for determination of reducing sugar. Anal. Chem. 31, 426-428. doi: 10.1021/ac60147a030

Mittler, R., Vanderauwera, S., Gollery, M., and Van Breusegem, F. (2004). Reactive oxygen gene network of plants. Trends Plant Sci. 9, 490-498. doi: 10.1016/j.tplants.2004.08.009

Mohd-Zaki, Z., Bastidas-Oyanedel, J., Lu, Y., Hoelzle, R., Pratt, S., Slater, F., et al. (2016). Influence of $\mathrm{pH}$ regulation mode in glucose fermentation on product selection and process stability. Microorganisms 4:2. doi: $10.3390 /$ microorganisms 4010002

Mupondwa, E., Li, X., Boyetchko, S., Hynes, R., and Geissler, J. (2015). Technoeconomic analysis of large scale production of pre-emergent Pseudomonas fluorescens microbial bioherbicide in Canada. Bioresour. Technol. 175, 517-528. doi: 10.1016/j.biortech.2014.10.130

Noll, L., Leonhardt, S., Arnstadt, T., Hoppe, B., Poll, C., Matzner, E., et al. (2016). Fungal biomass and extracellular enzyme activities in coarse woody debris of 13 tree species in the early phase of decomposition. For. Ecol. Manage. 378, 181-192. doi: 10.1016/j.foreco.2016.07.035

Papagianni, M. (2004). Fungal morphology and metabolite production in submerged mycelial processes. Biotechnol. Adv. 22, 189-259. doi: 10.1016/j.biotechadv.2003.09.005

Perotti, V. E., Larran, A. S., Palmieri, V. E., and Martinatto, A. K. (2020). Plant science Herbicide resistant weeds : a call to integrate conventional agricultural practices, molecular biology knowledge and new technologies. Plant Sci. 290:110255. doi: 10.1016/j.plantsci.2019.110255

Pongsawadi, P., and Yagisawa, M. (1987). Screening and identification of a cyclomaltoxtrinv glucanotransferase-producing bacteria. J. Ferment. Technol. 65, 463-467. doi: 10.1016/0385-6380(87)90144-0

Radhakrishnan, R., Alqarawi, A. A., and Abd_Allah, E. F. (2018). Bioherbicides: Current knowledge on weed control mechanism. Ecotoxicol. Environ. Saf. 158, 131-138. doi: 10.1016/j.ecoenv.2018.04.018

Ranimol, G., Venugopal, T., Gopalakrishnan, S., and Sunkar, S. (2018). Production of laccase from Trichoderma harzianum and its application in dye decolourisation. Biocatal. Agric. Biotechnol. 16, 400-404. doi: 10.1016/j.bcab.2018.09.003

Redda, E. T., Ma, J., Mei, J., Li, M., Wu, B., and Jiang, X. (2018). Biological control of soilborne pathogens (Fusarium oxysporum F. Sp. Cucumerinum) of Cucumber (Cucumis sativus) by Trichoderma sp. J. Life Sci. 12, 1-12. doi: 10.17265/1934-7391/2018.01.001

Reichert Júnior, F. W., Scariot, M. A., Forte, C. T., Pandolfi, L., Dil, J. M., Weirich, S., et al. (2019). New perspectives for weeds control using autochthonous fungi with selective bioherbicide potential. Heliyon 5:e01676. doi: 10.1016/j.heliyon.2019.e01676

Rodrigues, M., and Iemma, A. (2014). Experimental Design and Process Optimization, 1st Edn. Florida, FL: CRC Press. doi: 10.1201/b17848

Sander, K. B., and Murthy, G. S. (2009). "Enzymatic degradation of microalgal cell walls," in 2009 Reno, Nevada, June 21 - June 24, 2009 (St. Joseph, MI: American Society of Agricultural and Biological Engineers).

Schippers, J. H., Foyer, C. H., and van Dongen, J. T. (2016). Redox regulation in shoot growth, SAM maintenance and flowering. Curr. Opin. Plant Biol. 29, 121-128. doi: 10.1016/j.pbi.2015.11.009
Schneider, W. D. H., Fontana, R. C., Mendonça, S., de Siqueira, F. G., Dillon, A. J. P., and Camassola, M. (2018). High level production of laccases and peroxidases from the newly isolated white-rot basidiomycete Marasmiellus palmivorus VE111 in a stirred-tank bioreactor in response to different carbon and nitrogen sources. Process Biochem. 69, 1-11. doi: 10.1016/j.procbio.2018.03.005

Seppälä, S., Wilken, S. E., Knop, D., Solomon, K. V., and O’Malley, M. A. (2017). The importance of sourcing enzymes from non-conventional fungi for metabolic engineering and biomass breakdown. Metab. Eng. 44, 45-59. doi: 10.1016/j.ymben.2017.09.008

Stiles, W. A. V., Styles, D., Chapman, S. P., Esteves, S., Bywater, A., Melville, L., et al. (2018). Using microalgae in the circular economy to valorise anaerobic digestate: challenges and opportunities. Bioresour. Technol. 267, 732-742. doi: 10.1016/j.biortech.2018.07.100

Temudo, M. F., Kleerebezem, R., and Van Loosdrecht, M. (2007). Influence of the $\mathrm{pH}$ on (Open) mixed culture fermentation of glucose: a chemostat study. Biotechnol. Bioeng. 98, 69-79. doi: 10.1002/bit.21412

Todero, I., Confortin, T. C., Luft, L., Brun, T., Ugalde, G. A., de Almeida, T. C., et al. (2018). Formulation of a bioherbicide with metabolites from Phoma sp. Sci. Hortic. 241, 285-292. doi: 10.1016/j.scienta.2018. 07.009

Treichel, H., Sbardelotto, M., Venturin, B., Agnol, A. D., Mulinari, J., Golunski, S. M., et al. (2015). Lipase production from a newly isolated aspergillus niger by solid state fermentation using canola cake as substrate. Curr. Biotechnol. 6, 295-300. doi: 10.2174/2211550105666151124193225

Velazquez-Lucio, J., Rodríguez-Jasso, R. M., Colla, L. M., Sáenz-Galindo, A., Cervantes-Cisneros, D. E., Aguilar, C. N., et al. (2018). Microalgal biomass pretreatment for bioethanol production: a review. Biofuel Res. J. 5, 780-791. doi: 10.18331/BRJ2018.5.1.5

Vinale, F., Sivasithamparam, K., Ghisalberti, E. L., Marra, R., Woo, S. L., and Lorito, M. (2008). Trichoderma-plant-pathogen interactions. Soil Biol. Biochem. 40, 1-10. doi: 10.1016/j.soilbio.2007. 07.002

Vinale, F., Sivasithamparam, K., Ghisalbertic, E. L., Ruocco, M., Wood, S., and Lorito, M. (2012). Trichoderma secondary metabolites that affect plant metabolism. Nat. Prod. Commun. 7, 1545-1550. doi: 10.1177/1934578X1200701133

Wu, H., Walker, S., Rollin, M. J., Tan, D. K. Y., Robinson, G., and Werth, J. (2007). Germination, persistence, and emergence of flaxleaf fleabane (Conyza bonariensis [L.] Cronquist). Weed Biol. Manag. 7, 192-199. doi: 10.1111/j.1445-6664.2007.00256.x

Xie, S., Sun, S., Dai, S. Y., and Yuan, J. (2013). Efficient coagulation of microalgae in cultures with filamentous fungi. Algal Res. 2, 28-33. doi: 10.1016/j.algal.2012.11.004

Yeh, A.-I., Huang, Y.-C., and Chen, S. H. (2010). Effect of particle size on the rate of enzymatic hydrolysis of cellulose. Carbohydr. Polym. 79, 192-199. doi: 10.1016/j.carbpol.2009.07.049

Zeng, J., Dong, Z., Wu, H., Tian, Z., and Zhao, Z. (2017). Redox regulation of plant stem cell fate. EMBO J. 36, 2844-2855. doi: 10.15252/embj.201695955

Zhang, Y., Yang, X., Zhu, Y., Li, L., Zhang, Y., Li, J., et al. (2019). Biological control of Solidago canadensis using a bioherbicide isolate of Sclerotium rolfsii SC64 increased the biodiversity in invaded habitats. Biol. Control 139:104093. doi: 10.1016/j.biocontrol.2019. 104093

Conflict of Interest: The authors declare that the research was conducted in the absence of any commercial or financial relationships that could be construed as a potential conflict of interest.

Copyright (C) 2020 Stefanski, Camargo, Scapini, Bonatto, Venturin, Weirich, Ulkovski, Carezia, Ulrich, Michelon, Soares, Mathiensen, Fongaro, Mossi and Treichel. This is an open-access article distributed under the terms of the Creative Commons Attribution License (CC BY). The use, distribution or reproduction in other forums is permitted, provided the original author(s) and the copyright owner(s) are credited and that the original publication in this journal is cited, in accordance with accepted academic practice. No use, distribution or reproduction is permitted which does not comply with these terms. 